\title{
MAJAS SIMILE DALAM NOVEL AZAB DAN SENGSARA KARYA MERARI SIREGAR
}

\author{
Felta Lafamane \\ feltafamane@gmail.com \\ Universitas Haluoleo \\ Fakultas Sastra
}

\begin{abstract}
This study aims to identify the use of simile by Merari Siregar in novel's Azab dan Sengsara. This research is a qualitative research. The data is collected using the listening method used to obtain data by listening to the use of language. The data were analyzed descriptively and The data were analyzed based on the Kridalaksana word class manifestation theory and stylistic theory by Keraf. The type of data is written data, that is simile style language in the novel's Azab dan Sengsara by Merari Siregar.

The results showed that the embodiment of simile to Merari Siregar in novel's Azab dan Sengsara have five, namely (1) embodiment of simile in the noun class with nouns; (2) embodiment of simile in the noun class with adjectives; (3) embodiment of simile in the adjectives class with verb; (4) embodiment of simile in the verb class with verb; (5) embodiment of simile in the verb class with nouns. While, simile markers to Merari Siregar in novel's Azab dan Sengsara, namely sebagai, ibarat, seperti, tak ubahnya, laksana, dan seolah-olah.
\end{abstract}

Keywords: simile, novels, azab dan sengsara

\begin{abstract}
Abstrak
Penelitian ini bertujuan mengidentifikasi penggunaan majas simile dalam novel Azab dan Sengsara karya Merari Siregar. Penelitian ini merupakan penelitian kualitatif. Data dikumpulkan menggunakan metode simak, yakni metode yang digunakan untuk memperoleh data dengan melakukan penyimakan terhadap penggunaan bahasa. Data dianalisis secara deskriptif dan data dianalisis berdasarkan teori perwujudan kelas kata Kridalaksana dan teori gaya bahasa Keraf. Jenis datanya adalah data tertulis, yaitu majas simile dalam novel Azab dan Sengsara karya Merari Siregar.

Hasil penelitian menunjukkan bahwa perwujudan simile dalam novel Azab dan Sengsara ada lima, yakni (1) perwujudan simile dalam kelas kata nomina dengan nomina; (2) perwujudan simile dalam kelas kata nomina dengan adjektiva; (3) perwujudan simile dalam kelas kata adjektiva dengan verba; (4) perwujudan simile dalam kelas kata verba dengan verba; (5) perwujudan simile dalam kelas kata verba dengan nomina. Sementara, penanda simile yang digunakan oleh Merari Siregar dalam novel Azab dan Sengsara, yakni sebagai, ibarat, seperti, tak ubahnya, laksana, dan seolah-olah.
\end{abstract}

Kata kunci: simile, novel, azab dan sengsara

\section{PENDAHULUAN}

Wujud karya sastra mempunyai dua aspek penting, yakni isi dan bentuk. Isinya adalah tentang pengalaman hidup manusia, sedangkan bentuknya adalah segi-segi yang menyangkut cara penilaian, yaitu cara 
sastrawan memanfaatkan bahasa yang indah untuk mewadahi isinya (Semi, 1989:8). Bahasa merupakan unsur penting dalam karya sastra karena perannya sebagai sarana pengungkapan dan penyampaian pesan dalam karya sastra. Penggunaan bahasa dalam karya sastra berbeda dengan penggunaan bahasa dalam karya ilmiah misalnya ceramah, pidato dan sebagainya. Bahasa yang digunakan pengarang dalam suatu karya sastra merupakan gaya pembungkus idenya dalam mengekspresikan imajinasinya terhadap suatu objek sehingga sering disebut dengan gaya bahasa atau majas (style language).

Penggunaan gaya bahasa dalam karya sastra memiliki nilai rasa, seni, dan estetika yang tinggi yang dapat memperlihatkan ciri pribadi pengarang. Buffon (dalam Junus, 1989:20) menyatakan bahwa gaya adalah orang (penulis) itu sendiri. Dengan mengatakan gaya sebagai serangkaian ciri pribadi, pengarang dalam membuat karyanya akan memperlihatkan penggunaan bahasa yang khas dengan ciri atau karakteristik tersendiri yang berbeda dari pengarang lainnya.

Enkvist (dalam Junus, 1989:31) menyatakan bahwa gaya adalah sekumpulan ciri kolektif. Artinya, keberadaan gaya bersama dimiliki oleh dua orang pengarang atau lebih. Seperti yang diungkapkan oleh Junus (1989:34), bahwa jika dalam pengungkapan ciri pribadi yang ditonjolkan adalah perbedaan antara pengarang yang satu dengan pengarang lainnya, maka pada persoalan gaya sebagai ciri kolektif atau gaya sosial yang harus dicari adalah sekumpulan teks yang ditekankan pada hakikat persamaan.
Gaya bahasa atau majas dominan dipakai dalam karya-karya sastra seperti gaya bahasa perumpamaan (simile), metafora, personifikasi, litotes, alegori, hiperbola, dan masih banyak lagi. Dalam penelitian ini dikhususkan mengidentifikasi perwujudan gaya bahasa simile yang digunakan oleh Merari Siregar. Kekhasan perwujudan gaya bahasa simile oleh Merari Siregar dalam novel Azab dan Sengsara memperlihatkan ciri pribadinya dalam menulis jalan cerita dalam novel tersebut dan karakteristiknya menyelami karyakaryanya.

Karakteristik majas simile dalam novel Azab dan Sengsara sangat bervariatif. Hal ini dapat dilihat dari ranah terbanding dan ranah pembanding misalnya wujud nomina, verba, adjektiva, dan lain-lain. Penandapenanda pembanding juga sangat beragam misalnya kata seperti, laksana, ibarat, sebagai dan sebagainya.

Novel Azab dan Sengsara karya Merari Siregar lahir pada era Balai Pustaka. Tema Azab dan Sengsara mempermasalahkan perkawinan dalam hubungannya dengan harkat dan martabat keluarga. Penggunaan bahasa dalam novel Azab dan Sengsara bergaya melayu kesekolahan, melayu rendah, atau melayu pasar.

Secara umum novel Azab dan Sengsara memiliki ciri-ciri, yakni menguatnya kesadaran individu dan menipisnya kesadaran adat, kuat diwarnai penggambaran alam dan pengungkapan perasaan. Merari Siregar mempunyai karakteristik penceritaan dan gaya karya sastranya, yakni penggunaan bahasa yang lancar dan rapi dengan gaya khotbahnya langsung menunjukkan perkataan atau 
maksudnya kepada pembaca; meminta perhatian untuk ceritanya. Ia memberi nasihat, mengecam yang kurang baik serta memuji-muji tindakan yang menurut aturan masyarakat baik (Susiati, 2017:67)

Penelitian ini tidak terlepas dari berbagai macam penelitian yang relevan, di antaranya Munir dkk (2013:89) meneliti tentang Diksi dan Majas dalam Kumpulan Puisi Nyanyian dalam Kelam Karya Sutikno W. S: Kajian Stilistika. Hasil penelitiannya, yakni diksi yang ditemukan dalam kumpulan puisi Nyanyian dalam Kelam Karya Sutikno W. S adalah kata serapan dari bahasa Jawa, bahasa Asing, dan pemanfaatan sinonim. Sementara, majas yang ditemukan adalah majas perbandingan, metafora, perumpamaan (simile), epos, personifikasi, metonomia, sinekdoke, alegori.

Rachman dkk (2013:45) meneliti tentang Majas Metafora pada Kumpulan Sajak Chairil Anwar Aku Ini Binatang Jalang. Hasil penelitiannya, yakni ditemukan beberapa hal yang berkenaan dengan unsur batin seperti makna yang terdapat dalam tiap bait puisi dan puisi secara keseluruhan. Sementara, untuk bidang pengajaran hasil penelitian ini dapat membantu pelajar menemukan penggunaan majas metafora pada kumpulan sajak Chairil Anwar, masukan bagi guru Bahasa Indonesia untuk memilih karya sastra sebagai bahan ajar yang berhubungan dengan penggunaan majas metafora dalam melihat pemahaman siswa tentang makna puisi.

Penelitian ini bertujuan untuk mengidentifikasi majas simile oleh dalam novel Azab dan Sengsara karya Merari Siregar.

\section{LANDASAN TEORI}

\section{Pendekatan Stilistika}

Stilistika adalah ilmu yang mempelajari gaya bahasa yang merupakan bagian linguistik yang memusatkan pada variasivariasi penggunaan bahasa yang kompleks pada kesusatstraan. Sama halnya dengan pernyataan Endraswara (2003:72) yang menyebutkan bahwa stilistika adalah ilmu yang mempelajari gaya bahasa suatu karya sastra. Selanjutnya, ada dua pendekatan analisis stilistika, yaitu (1) dimulai dengan analisis sistem tentang linguistik karya sastra dan dilanjutkan ke interpretasi tentang ciri-ciri sastra, intrepretasi diarahkan ke makna secara total; (2) mempelajari sejumlah ciri khas yang membedakan satu sistem dengan sistem lain.

Sidjiman (1993:13), stilistika adalah style, yaitu cara yang digunakan seorang pembicara atau penulis untuk menyatakan maksudnya dengan menggunakan bahasa sebagai sarana.

Menurut Teeuw (dalam Fananie, 2000:25) menyatakan stilistika adalah sarana yang dipakai pengarang untuk mencapai suatu tujuan karena stilistika merupakan cara untuk mengungkapkan pikiran, jiwa, dan kepribadian pengarang dengan khasnya. Ratna (2016:167) secara definisi stilistika adalah ilmu yang berkaitan dengan gaya dan gaya bahasa tetapi pada umumnya lebih mengacu pada gaya bahasa.

\section{Gaya Bahasa}

Ahmadi (1990:170) menyatakan bahwa gaya bahasa adalah penggunaan bahasa yang istimewa, dan tidak dapat dipisahkan dari cara atau teknik seorang pengarang dalam 
merefleksikan (memantulkan dan mencerminkan) pengalaman, nilai-nilai kualitas kesadaran pikiran dan pandangan yang istimewa atau khusus. Ahmadi membagi gaya bahasa menjadi dua, yaitu gaya bahasa penekanan yang terdiri dari 25 jenis gaya bahasa dan gaya bahasa perbandingan yang terdiri dari empat belas jenis. Lain halnya Keraf (2010:113) yang menyebutkan bahwa gaya bahasa merupakan cara mengungkapkan pikiran melalui bahasa secara khas yang memperhatikan ciri dan kepribadian penulis (pemakai bahasa).

Menurut Kridalaksana (2011:76) gaya bahasa adalah pemanfaatan atas kekayaan bahasa oleh seseorang dalam bertutur atau menulis serta pemakaian ragam tertentu. Abrams (dalam Nurgiyantoro, 2002:276) gaya bahasa (style) adalah suatu hal yang pada umumnya tidak lagi mengandung sifat kontroversional, menyaran pada pengertian cara penggunaan bahasa dalam konteks tertentu, oleh pengarang tertentu dan sebagainya. Sementara, Menurut Jabrohim (2000:102) gaya bahasa merupakan penggunaan bahasa sebagai media komunikasi secara khusus, yaitu penggunaan bahasa secara bergaya dengan tujuan ekspresifitas pengucapan. Gaya bahasa meliputi seluruh unsur bahasa, yaitu intonasi, bunyi, kata, dan kalimat.

Keraf (2010:115) membagi jenis-jenis gaya bahasa sebagai berikut:

\section{1) Gaya Bahasa Berdasarkan Pilihan Kata}

Dalam bahasa standar (bahasa baku) dapatlah dibedakan: gaya bahasa resmi (bukan bahasa resmi), gaya bahasa tak resmi, dan gaya bahasa percakapan (Keraf, 2010:120).

\section{2) Gaya Bahasa Bedasarkan Nada}

Gaya bahasa dilihat dari segi nada yang terkandung dalam sebuah wacana, dibagi atas: gaya yang sederhana, gaya mulia dan bertenaga, serta gaya menengah.

\section{3) Gaya Bahasa Berdasarkan Struktur Kalimat}

Gaya bahasa berdasarkan struktur kalimat terdiri dari gaya bahasa klimaks, antiklimaks, paralelisme, antithesis, dan repetisi.

\section{4) Gaya Bahasa Berdasarkan Langsung Tidaknya Makna}

Berdasarkan langsung tidaknya makna yang terkandung dalam sebuah kata atau kelompok kata maka gaya bahasa dapat dibedakan atas dua bagian, yakni gaya langsung atau gaya bahasa retoris dan gaya bahasa kiasan.

\section{a) Gaya Bahasa Retoris}

Gaya bahasa retoris harus diartikan menurut nilai lahirnya.Tidak ada usaha menyembunyikan sesuatu di dalamnya (Keraf, 2010: 129). Gaya bahasa retoris terdiri dari aliterasi, asonansi, anastrof, apofasis atau preterisio, apostrof, asindeton, polisondeton, kiasmus, ellipsis, eufemisme, litotes, histeron, proteron, pleonasme dan tautologi, perifrasis, prolepsis atau antisipasi, erotesis atau pertanyaan retoris, silepsis dan zeugma, koreksio atau epanortosis, hiperbola, paradoks, dan oksimoron.

\section{b) Gaya Bahasa Kiasan}

Gaya bahasa kiasan ialah gaya yang dilihat dari segi makna tidak dapat ditafsirkan sesuai dengan kata-kata yang membentuknya. Makna harus dicari di luar 
rangkaian kata atau kalimatnya. Gaya bahasa kiasan terdiri atas persamaan atau simile, metafora, alegori, parabel, fabel, personifikasi, alusio, eponim, epitet, sonekdoke, metonomia, antonomasia, hipalase, ironi, sinisme, sarkasme, satire, inuendo, antifrasis, paronomasia.

\section{Simile}

Keraf (2010:138) menyatakan bahwa simile atau perumpamaan adalah perbandingan yang bersifat eksplisit yaitu gaya bahasa langsung menyatakan sesuatu sama dengan hal yang lain. Simile atau perumpamaan memerlukan ipaya yang secara eksplisit menunjukkan kesamaan itu, yaitu kata-kata: seperti, sama, sebagai, bagaikan, bagai, laksana, seolah-olah, tak ubahnya, dan sebagainya.

Menurut Tarigan (1986:144) simile atau perumpamaan adalah perbandingan dua hal yang pada hakekatnya berlainan dan dianggap sama. Perbandingan ini secara eksplisit dijelaskan dengan pemakaian kata seperti, sebagai, bagaikan, laksana, umpama, ibarat, dan sejenisnya.Contohnya kikirnya seperti kepiting batu.

Terdapat dua kata (atau bentuk lainnya) dalam simile atau perumpamaan yang masing-masing menampilkan konsep dan acuan yang berbeda. Menurut pandangan tiap budaya perumpamaan dalam sebuah bahasa dapat berbeda-beda bergantung dari latar belakang masyarakat tentang pengetahuan yang mereka pahami. Jadi, dalam simile dapat berupa perumpamaan secara orisinil atau perumpamaan secara kesepakatan kelompok masyarakat yang makna antara pembanding dan terbanding memiliki kesamaan komponen makna.
Dengan begitu, keduanya benda atau hal yang diperumpamakan bisa diperbandingkan. Perbandingan ini tidak menimbulkan masalah. Majas ini mudah dikenali karena kedua penanda muncul secara bersamaan dan selalu dihubungkan oleh kata pembandingnya.

\section{Contoh:}

\section{Tutur manisnya seperti madu}

Bagan wilayah makna yang diperumpamakan pada contoh di atas adalah frasa tutur manisnya dengan kata madu. Komponen makna penyama pada frasa tutur manisnya dan kata madu adalah merasa enak dan terpengaruh. Sementara, komponen makna pembeda, pada frasa tutur manisnya bermakna cara bertutur yang enak didengar, atau mengandung rayuan sehingga yang mendengarnya dapat terpengaruh. Sementara, kata madu merupakan cairan yang banyak mengandung zat gula yang rasanya manis sekali. Jadi, komponen makna penyama dan pembeda pada dua hal yang dipersamakan untuk frasa tuturmanisnya terletak pada cara dan pada kata madu terletak pada sifatnya.

Simile menyaran pada adanya perbandingan yang langsung dan eksplisit dengan mempergunakan kata-kata tugas tertentu sebagai penanda keeksplisitan seperti: seperti, bagai, bagaikan, sebagai, laksana, mirip, dan sebagainya (Nurgiyantoro, 2014:298).

\section{Perwujudan Kelas Kata}

Kridalaksana (2011:110), kata adalah morfem atau kombinasi morfem yang oleh bahasawan dianggap sebagai satuan terkecil yang dapat diujarkan sebagai bentuk yang bebas atau satuan bahasa yang dapat berdiri 
sendiri, terjadi dari morfem tunggal atau morfem gabungan. Kata tunggal atau morfem tunggal adalah kata yang berasal dari leksem tunggal setelah mengalami proses morfologi. Kata kompleks adalah kata yang sudah mengalami proses morfologis. Kata golongan ini dapat dibedakan menjadi tiga, yaitu (1) kata berimbuhan; (2) kata ulang; (3) kata majemuk. Kata berimbuhan adalah kata yang dibentuk dengan proses afiksasi, sedangkan kata ulang adalah kata yang dibentuk dengan proses reduplikasi. Menurut

Kridalaksana (2009:28) kata majemuk adalah gabungan morfem dasar yang seluruhnya berstatus sebagai kata yang mempunyai pola fonologis, gramatikal, dan semantik yang khusus menurut kaidah yang bersangkutan. Kridalaksana (2009:29) menggolongkan kelas kata menjadi tiga belas kata, yaitu verba (kata kerja), adjektiva (kata sifat), nomina (kata benda), pronomina (kata ganti), numeralia (kata bilangan), adverbia (kata keterangan), interogativa (kata tanya), demonstrativa (kata tunjuk), preposisi (kata depan), konjungsi (kata penghubung), artikula, kategori fatis, dan interjeksi (kata seru).

\section{METODE PENELITIAN}

\section{Jenis penelitian dan Pendekatan}

Penelitian ini merupakan jenis penelitian deskriptif kualitatif dengan menggunakan pendekatan stilistika. Jenis penelitian deskriptif kualitatif, yakni salah satu prosedur penelitian yang menghasilkan data deskriptif berupa ucapan atau tulisan dan perilaku orang-orang yang diamati (Bodgan dan Taylor dalam Moleong, 2007:67).
Sementara, pendekatan stilistika, yaitu memberikan perhatian terhadap tampilan bahasa di dalam karya sastra.

\section{Metode dan Teknik Pengumpulan Data}

Metode yang digunakan dalam penelitian ini adalah metode simak. Menurut Mahsun (2013:242) metode simak adalah metode yang digunakan untuk memperoleh data dengan melakukan penyimakan terhadap penggunaan bahasa. Teks dalam novel Azab dan Sengsara karya Merari Siregar disimak dan diamati untuk mencari penggunaan perwujudan majas simile yang terdapat dalam novel Azab dan Sengsara karya Merari Siregar, kemudian ditandai, serta didokumentasikan untuk diinventarisasikan sebagai data dalam penelitian ini. Adapun teknik yang digunakan untuk melengkapi metode simak tersebut adalah teknik catat.

Teknik catat adalah teknik yang digunakan untuk mencatat data yang ditemukan. Teknik catat merupakan teknik yang digunakan untuk mencatat beberapa bentuk yang relevan bagi penelitian yang bersumber dari penggunaan bahasa secara tertulis (Mahsun, 2013:127). Teks novel Azab dan Sengsara karya Merari Siregar dibaca, kemudian menandai kata-kata dalam teks novel yang mengandung majas simile. Semua data yang telah ditandai dalam novel Azab dan Sengsara karya Merari Siregar, selanjutnya disalin dalam kartu data untuk dianalisis perwujudannya.

\section{Sumber dan Jenis Data}

Sumber data penelitian ini adalah novel novel Azab dan Sengsara karya Merari Siregar terbitan PT. Balai Pustaka, cetakan kedua belas, Jakarta (1993). 
Jenis data dalam penelitian ini adalah data tertulis, yaitu majas simile dalam novel novel Azab dan Sengsara karya Merari Siregar.

\section{Teknis Analisis Data}

Analisis data dalam penelitian ini sebagai berikut:

1. Pengidentifikasian data, yakni mengidentifikasi perwujudan simile melalui teks dalam novel Azab dan Sengsara karya Merari Siregar.

2. Pengklasifikasian data, yakni mengklasifikasi teks yang menunjukkan perwujudan simile dalam novel $A z a b$ dan Sengsara karya Merari Siregar.

3. Penganalisisan data, yakni semua data yang telah diklasifikasi dianalisis dengan mendeskripsikan secara mendetail permasalahan yang ada dalam penelitian ini berupa perwujudan simile oleh Merari Siregar dalam novel Azab dan Sengsara.

\section{PEMBAHASAN}

Pembahasan dalam penelitian ini akan mengidentifikasi perwujudan simile oleh Merari Siregar dalam novel Azab dan Sengsara yang menjadi fokus masalah.

\section{Perwujudan Simile dalam Novel Azab dan Sengsara}

Perwujudan Simile oleh Merari Siregar dalam Kelas Kata Nomina dengan Nomina

\begin{tabular}{|c|c|c|c|c|c|c|}
\hline No & $\begin{array}{c}\text { Kutipan Teks } \\
\text { Novel Azab dan } \\
\text { Sengsara }\end{array}$ & \multicolumn{2}{|l|}{ Perwujudan Nomina } & $\begin{array}{c}\text { Penanda } \\
\text { terbanding dan } \\
\text { Pembanding }\end{array}$ & $\begin{array}{c}\text { Terbanding } \\
\text { (Teb) }\end{array}$ & $\begin{array}{c}\text { Pembanding } \\
\text { (Pem) }\end{array}$ \\
\cline { 3 - 6 } & $\begin{array}{l}\text { Langit di sebelah } \\
\text { barat pun merah } \\
\text { kuning rupanya } \\
\text { dan sinar matahari }\end{array}$ & $\begin{array}{l}\text { Nomina } \\
\text { konkret }\end{array}$ & $\begin{array}{l}\text { Nomina } \\
\text { konkret }\end{array}$ & Sebagai & $\begin{array}{l}\text { Langit di } \\
\text { sebelah barat } \\
\text { pun merah } \\
\text { kuning }\end{array}$ & Emas juwita \\
\hline
\end{tabular}

Perwujudan simile dalam novel $A z a b$ dan Sengsara sangat bervariasi, yakni berwujud nomina, verba, adjektiva

Dalam mengidentifikasi perwujudan simile dalam novel Azab dan Sengsara, penulis menggunakan teori perwujudan kelas kata Kridalaksana dan teori gaya bahasa Keraf. Adapun perwujudan simile dalam novel Azab dan Sengsara, yakni (1) perwujudan simile dalam kelas kata nomina dengan nomina; (2) perwujudan simile dalam kelas kata nomina dengan adjektiva; (3) perwujudan simile dalam kelas kata adjektiva dengan verba; (4) perwujudan simile dalam kelas kata verba dengan verba; (5) perwujudan simile dalam kelas kata verba dengan nomina. Sementara, penanda simile yang digunakan oleh Merari Siregar dalam novel Azab dan Sengsara, yakni sebagai, ibarat, seperti, tak ubahnya, laksana, dan seolah-olah. Berikut penjelasannya.

\section{Perwujudan Simile dalam Kelas Kata Nomina dengan Nomina}

Perwujudan simile Merari Siregar meliputi terbanding dan pembanding. Adapun terbanding berwujud nomina konkret dan nomina abstrak, begitu pula dengan pembanding berwujud nomina konkret dan nomina abstrak. Gaya bahasa simile Merari Siregar dengan Perwujudan nomina dengan nomina dalam novel Azab dan Sengsara dapat dilihat pada tabel 1 di bawah ini.

\section{Tabel 1}




\begin{tabular}{|c|c|c|c|c|c|c|}
\hline & $\begin{array}{l}\text { yang turun itu } \\
\text { nampaklah di atas } \\
\text { kayu yang tinggi- } \\
\text { tinggi, indah } \\
\text { rupanya sebagai } \\
\text { disepuh dengan } \\
\text { emas juwita. } \\
\text { (hlm.11) }\end{array}$ & & & & & \\
\hline 2 & $\begin{array}{l}\text { Batang padi yang } \\
\text { tumbuh di sawah } \\
\text { yang luas itupun } \\
\text { dibuai-buaikan } \\
\text { angin sebagai } \\
\text { ombak yang } \\
\text { berpalu-paluandi } \\
\text { atas laut yang } \\
\text { lebar. (hlm.11) }\end{array}$ & $\begin{array}{l}\text { Nomina } \\
\text { konkret }\end{array}$ & $\begin{array}{l}\text { Nomina } \\
\text { konkter }\end{array}$ & Sebagai & $\begin{array}{l}\text { Batang padi } \\
\text { yang tumbuh } \\
\text { di sawah yang } \\
\text { luas itupun } \\
\text { dibuai-buaikan } \\
\text { angin }\end{array}$ & $\begin{array}{l}\text { Ombak yang } \\
\text { berpalu-paluan } \\
\text { di atas laut } \\
\text { yang lebar }\end{array}$ \\
\hline 3 & $\begin{array}{l}\text { Sawah yang luas } \\
\text { itupun tak } \\
\text { ubahnya dengan } \\
\text { lautan. (hlm.11) }\end{array}$ & $\begin{array}{l}\text { Nomina } \\
\text { konkret }\end{array}$ & $\begin{array}{l}\text { Nomina } \\
\text { konkret }\end{array}$ & Tak ubahnya & $\begin{array}{l}\text { Sawah yang } \\
\text { luas }\end{array}$ & Lautan \\
\hline 4 & $\begin{array}{l}\text { Nasib manusia itu } \\
\text { sebagai roda, } \\
\text { kadang-kadang ke } \\
\text { atas, kadang- } \\
\text { kadang ke bawah } \\
\text { (hlm.16) }\end{array}$ & $\begin{array}{c}\text { Nomina } \\
\text { abstrak }\end{array}$ & $\begin{array}{l}\text { Nomina } \\
\text { konkret }\end{array}$ & Sebagai & Nasib manusia & Roda \\
\hline 5 & $\begin{array}{l}\text { Ah, sungguh saya } \\
\text { merasa beruntung } \\
\text { karena anak kita } \\
\text { ini sebagai } \\
\text { matahari yang } \\
\text { menyinari } \\
\text { peernikahan kita. } \\
\text { (hlm. 26) }\end{array}$ & $\begin{array}{c}\text { Nomina } \\
\text { konkret } \\
\text { bernyawa }\end{array}$ & $\begin{array}{l}\text { Nomina } \\
\text { konkret }\end{array}$ & Sebagai & Anak & Matahari \\
\hline 6 & $\begin{array}{l}\text { Hatinya hancur } \\
\text { sebagai kaca } \\
\text { terempas ke batu . } \\
\text {. . (hlm.32) }\end{array}$ & $\begin{array}{c}\text { Nomina } \\
\text { abstrak }\end{array}$ & $\begin{array}{l}\text { Nomina } \\
\text { konkret }\end{array}$ & Sebagai & $\begin{array}{l}\text { Hati yang } \\
\text { hancur }\end{array}$ & $\begin{array}{l}\text { Kaca terempas } \\
\text { ke batu }\end{array}$ \\
\hline 7 & $\begin{array}{l}\text { Sipipisan pun } \\
\text { sudah hilang } \\
\text { puncaknya yang } \\
\text { bagus itu, } \\
\text { bentuknya sebagai } \\
\text { bentuk ranggah } \\
\text { ayam jantan yang } \\
\text { berdiri dengan } \\
\text { gagahnya. (hlm. } \\
\text { 38) }\end{array}$ & $\begin{array}{l}\text { Nomina } \\
\text { konkret }\end{array}$ & $\begin{array}{l}\text { Nomina } \\
\text { konkret }\end{array}$ & Sebagai & $\begin{array}{l}\text { Sipipisan pun } \\
\text { sudah hilang } \\
\text { puncaknya }\end{array}$ & $\begin{array}{l}\text { bentuk } \\
\text { ranggah ayam } \\
\text { jantan yang } \\
\text { berdiri dengan } \\
\text { gagahnya }\end{array}$ \\
\hline
\end{tabular}


Contoh (1)

Langit di sebelah barat pun merah kuning rupanya dan sinar matahari yang turun itu nampaklah di atas kayu yang tinggi-tinggi, indah rupanya sebagai disepuh dengan emas juwita. (hlm.11)

Bagan wilayah terbanding dan pembanding yang diperumpamakan pada contoh di atas, yang termasuk terbanding adalah kalimat langit di sebelah barat pun merah kuning rupanya dengan pembanding frasa emas juwita. Komponen makna penyama pada kalimat langit di sebelah barat pun merah kuning rupanya dan frasa emas juwita adalah kesamaan warna, yakni sama-sama menghasilkan warna kekuningan. Sementara, komponen makna pembeda, pada kalimat langit di sebelah barat pun merah kuning rupanya bermakna warna langit ketika matahari terbenam. Sementara, frasa emas juwita bermakna emas yang berwarna kuning kemerahmerahan. Jadi, warna kekuningan yang dihasilkan oleh matahari yang terbenam diasosiasikan dengan warna emas juwita karena memiliki komponen makna penyama. Penanda simile antara pembanding dan terbanding pada contoh di atas adalah kata sebagai.

Contoh (2)

Batang padi yang tumbuh di sawah yang luas itupun dibuai-buaikan angin sebagai ombak yang berpalu-paluandi atas laut yang lebar. (hlm.11)

Penanda simile antara terbanding dan pembanding pada contoh di atas adalah kata sebagai. Bagan wilayah terbanding dan pembanding yang diperumpamakan pada contoh di atas, yaitu kalimat Batang padi yang tumbuh di sawah yang luas itupun dibuai-buaikan angin merupakan terbanding dan kalimat ombak yang berpalu-paluan di atas laut yang lebar merupakan pembanding. Komponen makna penyama pada kalimat Batang padi yang tumbuh di sawah yang luas itupun dibuai-buaikan angin dan kalimat ombak yang berpalupaluan di atas laut yang lebar adalah diayun-ayunkan dan berpukul-pukulan. Sementara, komponen makna pembeda, pada kalimat Batang padi yang tumbuh di sawah yang luas itupun dibuai-buaikan angin bermakna batang padi yang bergerakgerak karena tertiup oleh angin. Sementara, kalimat ombak yang berpalu-paluan di atas laut yang lebar bermakna ombak yang begelombang. Jadi, batang padi yang dibuaibuaikan angin diasosiasikan dengan bentuk ombak yang berpalu-paluan karena memiliki komponen makna penyama.

Contoh (3)

Sawah yang luas itupun tak ubahnya dengan lautan. (hlm.11)

Bagan wilayah terbanding dan pembanding yang diperumpamakan pada contoh di atas, antara lain yang termasuk terbanding adalah kalimat Sawah yang luas dan pembanding adalah kata lautan. Komponen makna penyama pada kalimat Sawah yang luas dan kata lautan adalah lapang; lebar suatu bidang atau ruang. Jadi, sawah yang luas diasosiasikan dengan bentuk lautan yang luas. Sementara, komponen makna pembeda, pada kalimat sawah yang luas bermakna sawah yang ukurannya sangat lebar bidangnya. Sementara, kata lautan bermakna samudera. Penanda simile antara pembanding dan 
terbanding pada contoh di atas adalah kata tak ubahnya.

\section{Perwujudan Simile dalam Kelas Kata Nomina dengan Adjektiva}

Perwujudan simile meliputi terbanding dan pembanding. Adapun terbanding berwujud nomina konkret, nomina abstrak dan adjektiva, begitupula dengan pembanding berwujud nomina konkret, nomina abstrak, dan adjektiva. Perwujudan gaya bahasa simile dalam kelas kata nomina dengan adjektiva pada novel Azab dan Sengsara, sebagai berikut:

\section{Tabel 2}

Perwujudan Simile oleh Merari Siregar dalam Kelas Kata Nomina dengan Adjektiva

\begin{tabular}{|c|c|c|c|c|c|c|}
\hline \multirow[t]{2}{*}{ No } & \multirow{2}{*}{$\begin{array}{c}\text { Kutipan Teks } \\
\text { Novel Azab dan } \\
\text { Sengsara }\end{array}$} & \multicolumn{2}{|c|}{ Perwujudan Nomina } & \multirow{2}{*}{$\begin{array}{c}\text { Penanda } \\
\text { terbanding } \\
\text { dan } \\
\text { pembanding }\end{array}$} & \multirow{2}{*}{$\begin{array}{c}\text { Terbanding } \\
(\mathrm{Teb})\end{array}$} & \multirow{2}{*}{$\begin{array}{c}\text { Pembanding } \\
(\text { Pem })\end{array}$} \\
\hline & & Teb & Pem & & & \\
\hline 1 & $\begin{array}{l}\text { Pengetahuannya } \\
\text { tiada suatu apa } \\
\text { ibarat gendeng } \\
\text { kalau dipalu } \\
\text { keras suaranya, } \\
\text { dibelah tak ada } \\
\text { isinya (hlm.31) }\end{array}$ & $\begin{array}{l}\text { Nomina } \\
\text { abstrak }\end{array}$ & Adjektiva & Ibarat & $\begin{array}{l}\text { Pengetahuannya } \\
\text { tiada suatu apa }\end{array}$ & Gendeng \\
\hline 2 & $\begin{array}{l}\text { Lihatlah warna } \\
\text { kulitnya yang } \\
\text { jernih dan bersih } \\
\text { itu, putih kuning } \\
\text { sebagai kulit } \\
\text { langsat. (hlm.33) }\end{array}$ & Adjektiva & $\begin{array}{l}\text { Nomina } \\
\text { konkret }\end{array}$ & Sebagai & $\begin{array}{l}\text { Warna kulitnya } \\
\text { yang jernih dan } \\
\text { bersih itu, putih } \\
\text { kuning }\end{array}$ & Kulit langsat \\
\hline 3 & $\begin{array}{l}\text { Giginya yang } \\
\text { putih dan halus, } \\
\text { berkilat-kilat } \\
\text { sebagai mutiara. } \\
\text { (hlm.33) }\end{array}$ & Adjektiva & $\begin{array}{l}\text { Nomina } \\
\text { konkret }\end{array}$ & Sebagai & $\begin{array}{l}\text { Giginya yang } \\
\text { putih dan halus }\end{array}$ & Mutiara \\
\hline 4 & $\begin{array}{l}\text { Air matanya } \\
\text { yang hening dan } \\
\text { jernih, suci dan } \\
\text { basah sebagai seri } \\
\text { gunung waktu } \\
\text { matahari akan } \\
\text { terbenam adanya } \\
\text { (hlm.33) }\end{array}$ & Adjektiva & $\begin{array}{l}\text { Nomina } \\
\text { konkret }\end{array}$ & Sebagai & $\begin{array}{l}\text { Air matanya } \\
\text { yang hening } \\
\text { dan jernih, suci } \\
\text { dan basah }\end{array}$ & $\begin{array}{l}\text { Seri gunung } \\
\text { waktu } \\
\text { matahari akan } \\
\text { terbenam }\end{array}$ \\
\hline 5 & $\begin{array}{l}\text { Hari yang kelam } \\
\text { itu menjadi kelam } \\
\text { sebagai waktu } \\
\text { matahari } \\
\text { terbenam. (hlm. } \\
\text { 38) }\end{array}$ & Adjektiva & $\begin{array}{l}\text { Nomina } \\
\text { konkret }\end{array}$ & Sebagai & $\begin{array}{l}\text { Hari yang } \\
\text { kelam itu } \\
\text { menjadi kelam }\end{array}$ & $\begin{array}{l}\text { Waktu } \\
\text { matahari } \\
\text { terbenam }\end{array}$ \\
\hline 6 & $\begin{array}{l}\text { Terasa benar- } \\
\text { benar dalam } \\
\text { hatiku: makin }\end{array}$ & Adjektiva & $\begin{array}{l}\text { Nomina } \\
\text { konkret }\end{array}$ & Sebagai & Besar cinta & $\begin{array}{l}\text { Tanam- } \\
\text { tanaman }\end{array}$ \\
\hline
\end{tabular}




\begin{tabular}{|l|l|l|l|l|l|l|}
\hline & $\begin{array}{l}\text { lama makin besar } \\
\text { cinta itu sebagai } \\
\text { tanam-tanaman. } \\
\text { (hlm.71) }\end{array}$ & & & & \\
\hline 7 & $\begin{array}{l}\text { Akan tetapi cita- } \\
\text { cita itu sudah } \\
\text { lenyap sebagai } \\
\text { kabut ditiup } \\
\text { angin. (hlm. }\end{array}$ & Adjektiva & $\begin{array}{l}\text { Nomina } \\
\text { konkret }\end{array}$ & Sebagai & $\begin{array}{l}\text { Cita-cita itu } \\
\text { sudah lenyap }\end{array}$ & $\begin{array}{l}\text { Kabut ditiup } \\
\text { angin }\end{array}$ \\
\hline
\end{tabular}

Contoh (4)

Pengetahuannya tiada suatu apa ibarat gendeng kalau dipalu keras suaranya, dibelah tak ada isinya (hlm.31)

Bagan wilayah terbanding dan pembanding yang diperumpamakan pada contoh di atas, meliputi kalimat pengetahuannya tiada suatu apa yang merupakan terbanding dan kata gendeng merupakan pembanding. Komponen makna penyama pada kalimat pengetahuannya tiada suatu apa dan kata gendeng adalah bodoh; tidak punya pengetahuan. Sementara, komponen makna pembeda, pada kalimat pengetahuannya tiada suatu apa bermakna tidak pintar; kurang pintar. Sementara, kata gendeng bermakna gila; tidak normal. Jadi, pengetahuannya tiada suatu apa diasosiasikan dengan gendeng karena mempunyai komponen makna penyama. Penanda simile antara pembanding dan terbanding pada contoh di atas adalah kata ibarat.

\section{Contoh (5)}

Lihatlah warna kulitnya yang jernih dan bersih itu, putih kuning sebagai kulit langsat. (hlm.33)

Bagan wilayah terbanding dan pembanding yang diperumpamakan pada contoh di atas adalah kalimat warna kulitnya yang jernih dan bersih itu, putih kuning merupakan terbanding dan frasa kulit langsat merupakan pembanding. Komponen makna penyama pada kalimat warna kulitnya yang jernih dan bersih itu, putih kuning dan frasa kulit langsat adalah putih bersih. Sementara, komponen makna pembeda, pada kalimat warna kulitnya yang jernih dan bersih itu, putih kuning bermakna mempunyai kulit yang putih kekuningkuningan. Sementara, frasa kulit langsat bermakna kulit buah yang berwarna putih atau kuning; buahnya menyerupai duku. Jadi, warna kulitnya yang jernih dan bersih itu, putih kuning disamakan dengan kulit langsat karena mempunyai komponen makna penyama. Penanda simile antara terbanding dan pembanding pada contoh di atas adalah kata sebagai.

\section{Contoh (6)}

Giginya yang putih dan halus, berkilatkilat sebagai mutiara. (hlm.33)

Bagan wilayah terbanding dan pembanding yang diperumpamakan pada contoh di atas adalah kalimat giginya yang putih dan halus, berkilat-kilat merupakan terbanding dan kata mutiara merupakan pembanding. Komponen makna penyama pada kalimat giginya yang putih dan halus, berkilat-kilat dan kata mutiara adalah putih bersih; mengkilat. Sementara, komponen makna pembeda, pada kalimat giginya yang putih dan halus, berkilat-kilat bermakna 
mempunyai bentuk giginya yang putih, bersih, dan berkilat. Sementara, kata mutiara bermakna permata berbentuk bulat dan keras yang berwarna putih. Jadi, giginya yang putih dan halus, berkilat-kilat diasosiasikan dengan mutiara karena mempunyai komponen makna penyama. Penanda simile antara pembanding dan terbanding pada contoh di atas adalah kata sebagai.

\section{Perwujudan Simile dalam Kelas Kata Adjektiva dengan Verba}

Perwujudan simile meliputi terbanding dan pembanding. Adapun terbanding berwujud adjektiva dan verba begitupula dengan pembanding berwujud adjektiva dan verba. Perwujudan simile dalam kelas kata adjektiva dengan Verba pada novel $A z a b$ dan Sengsara, sebagai berikut:

\section{Tabel 3}

\section{Perwujudan Simile oleh Merari Siregar dalam Kelas Kata Adjektiva dengan Verba}

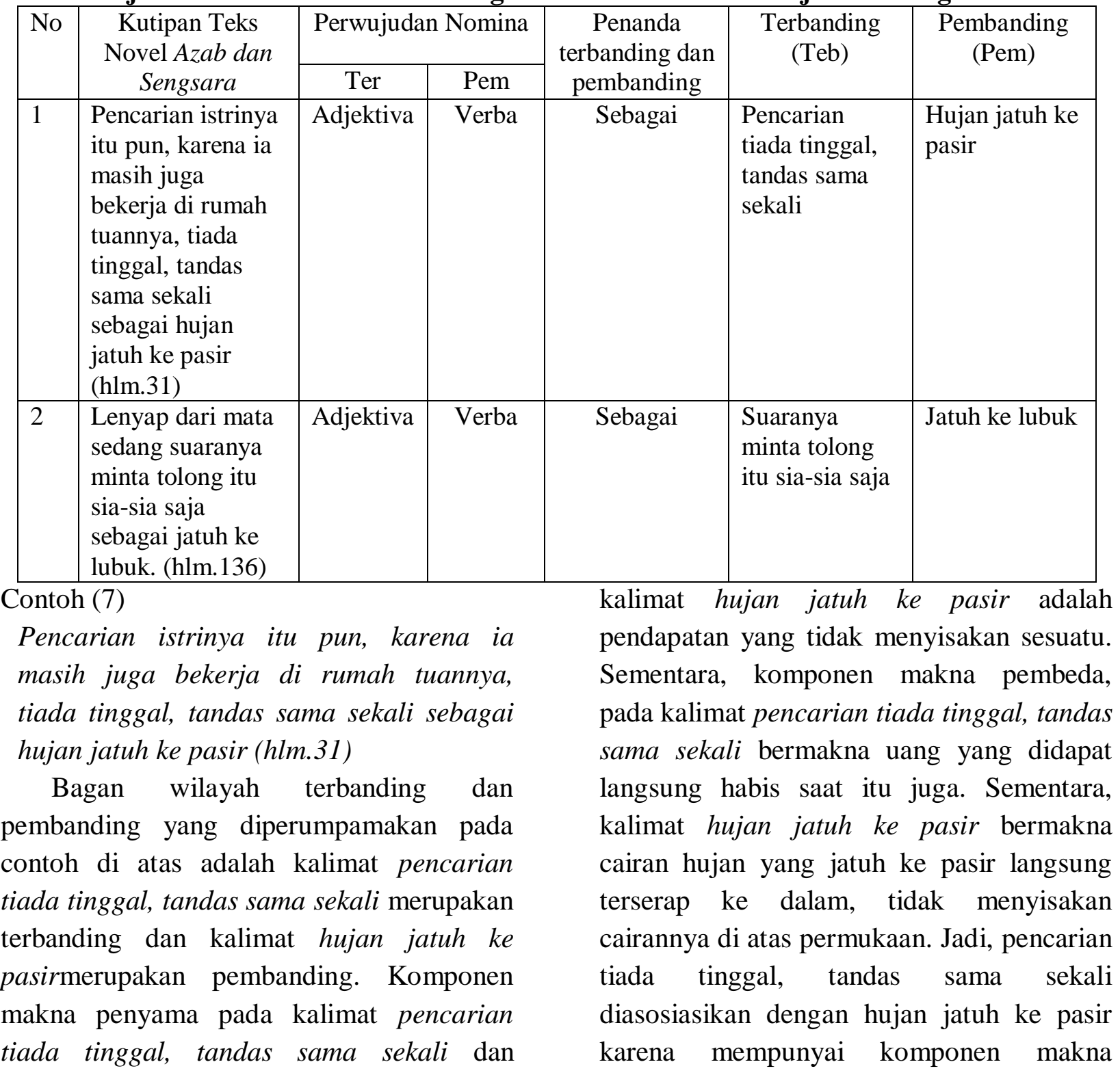


penyama. Penanda simile antara pembanding dan terbanding pada contoh di atas adalah kata sebagai.

\section{Contoh (8)}

Lenyap dari mata sedang suaranya minta tolong itu sia-sia saja sebagai jatuh ke lubuk. (hlm.136)

Bagan wilayah terbanding dan pembanding yang diperumpamakan pada contoh di atas, yakni yang termasuk terbanding adalah kalimat suaranya minta tolong itu sia-sia saja dan pembanding adalah kalimat jatuh ke lubuk. Komponen makna penyama pada kedua contoh kalimat tersebut adalah sesuatu yang tak terdengar atau lenyap. Sementara, komponen makna pembeda, pada kalimat suaranya minta tolong itu sia-sia saja bermakna suatu teriakan yang semakin hilang tidak terdengar. Sementara, kalimat jatuh ke lubuk bermakna sesuatu yang jatuh ke dasar yang terdalam tak terlihat; hilang lenyap. Jadi, suaranya minta tolong itu sia-sia saja diasosiasikan dengan jatuh ke lubuk karena mempunyai komponen makna penyama. Penanda simile antara pembanding dan terbanding pada contoh di atas adalah kata sebagai.

\section{Perwujudan Simile dalam Kelas Kata Verba dengan Verba}

Perwujudan simile meliputi terbanding dan pembanding. Adapun terbanding dan pembanding berwujud verba dan verba. Perwujudan simile dalam kelas kata verba dengan Verba pada novel Azab dan Sengsara, sebagai berikut:

\section{Tabel 4}

Perwujudan Simile oleh Merari Siregar dalam Kelas Kata Verba dengan Verba

\begin{tabular}{|l|l|l|c|c|l|l|}
\hline No & $\begin{array}{l}\text { Kutipan Teks } \\
\text { Novel Azab dan } \\
\text { Sengsara }\end{array}$ & \multicolumn{2}{|l|}{ Perwujudan Nomina } & $\begin{array}{c}\text { Penanda } \\
\text { terbanding dan } \\
\text { pembanding }\end{array}$ & $\begin{array}{c}\text { Terbanding } \\
\text { (Teb) }\end{array}$ & $\begin{array}{c}\text { Pembanding } \\
\text { (Pem) }\end{array}$ \\
\cline { 3 - 6 } & $\begin{array}{l}\text { Kalau matahari } \\
\text { hendak masuk ke } \\
\text { perhentiannya, ia } \\
\text { akan } \\
\text { memancarkan } \\
\text { sinar yang seperti } \\
\text { emas disepuh ke } \\
\text { puncak gunung } \\
\text { (hlm.48) }\end{array}$ & Verba & Verba & Seperti & $\begin{array}{l}\text { Kalau } \\
\text { matahari } \\
\text { hendak masuk } \\
\text { ke } \\
\text { perhentiannya, } \\
\text { ia akan } \\
\text { memancarkan } \\
\text { sinar }\end{array}$ & $\begin{array}{l}\text { Emas disepuh } \\
\text { ke puncak } \\
\text { gunung }\end{array}$ \\
\hline 2 & $\begin{array}{l}\text { Air matanya } \\
\text { bercucuran, } \\
\text { laksana mutiara } \\
\text { yang gugur dari } \\
\text { karangnya. } \\
\text { (hlm.77) }\end{array}$ & Verba & Verba & Laksana & $\begin{array}{l}\text { Air matanya } \\
\text { bercucuran }\end{array}$ & $\begin{array}{l}\text { Mutiara yang } \\
\text { gugur dari } \\
\text { karangnya }\end{array}$ \\
\hline 3 & $\begin{array}{l}\text { Tiadalah } \\
\text { diketahuinya air } \\
\text { matanya jatuh } \\
\text { bertititk-titik } \\
\text { sebagai air } \\
\text { mayang enau baru }\end{array}$ & Verba & Verba & Sebagai & $\begin{array}{l}\text { Diketahuinya } \\
\text { air matanya } \\
\text { jatuh bertititk- } \\
\text { titik }\end{array}$ & $\begin{array}{l}\text { Air mayang } \\
\text { enau baru } \\
\text { dipancung }\end{array}$ \\
\hline
\end{tabular}




\begin{tabular}{|c|c|c|c|c|c|c|}
\hline & $\begin{array}{l}\text { dipancung. } \\
\text { (hlm.104) }\end{array}$ & & & & & \\
\hline 4 & $\begin{array}{l}\text { Tetapi meskipun } \\
\text { ia lambat-lambat } \\
\text { turun ke sebelah } \\
\text { barat sebagai raja } \\
\text { berjalan lakunya. . } \\
\text {. (hlm.129) }\end{array}$ & Verba & Verba & Sebagai & $\begin{array}{l}\text { ia lambat- } \\
\text { lambat turun } \\
\text { ke sebelah } \\
\text { barat }\end{array}$ & $\begin{array}{l}\text { Raja berjalan } \\
\text { lakunya }\end{array}$ \\
\hline 5 & $\begin{array}{l}\text { Karena pohon } \\
\text { tembakau pada } \\
\text { waktu itu telah } \\
\text { tinggi, sehingga } \\
\text { badan mereka itu } \\
\text { kelindungan } \\
\text { hanya kepala } \\
\text { sajalah yang } \\
\text { terulur ke atas } \\
\text { sebagai terapung } \\
\text { di atas laut } \\
\text { rupanya. (hlm. } \\
\text { 129) }\end{array}$ & Verba & Verba & Sebagai & $\begin{array}{l}\text { kepala sajalah } \\
\text { yang terulur } \\
\text { ke atas }\end{array}$ & $\begin{array}{l}\text { terapung di } \\
\text { atas laut } \\
\text { rupanya }\end{array}$ \\
\hline 6 & $\begin{array}{l}\text { Terpancarlah } \\
\text { sinarnya yang } \\
\text { amat permai itu, } \\
\text { keluar dari pada } \\
\text { suatu benda yang } \\
\text { bundar sebagai } \\
\text { anak panah yang } \\
\text { melayang } \\
\text { daripada } \\
\text { busurnya. } \\
\text { (hlm.132) }\end{array}$ & Verba & Verba & Sebagai & $\begin{array}{l}\text { Terpancarlah } \\
\text { sinarnya }\end{array}$ & $\begin{array}{l}\text { anak panah } \\
\text { yang } \\
\text { melayang } \\
\text { daripada } \\
\text { busurnya }\end{array}$ \\
\hline 7 & $\begin{array}{l}\text { Layar pun } \\
\text { terkembang } \\
\text { semua sebagai } \\
\text { sayap burung } \\
\text { yang sedang } \\
\text { melayang di } \\
\text { udara. (hlm. } 148 \text { ) }\end{array}$ & Verba & Verba & Sebagai & $\begin{array}{l}\text { Layar pun } \\
\text { terkembang }\end{array}$ & $\begin{array}{l}\text { Sayap burung } \\
\text { yang sedang } \\
\text { melayang di } \\
\text { udara }\end{array}$ \\
\hline
\end{tabular}

\section{Contoh (9)}

Kalau matahari hendak masuk ke perhentiannya, ia akan memancarkan sinar yang seperti emas disepuh ke puncak gunung (hlm.48)

Bagan wilayah terbanding dan pembanding yang diperumpamakan pada contoh di atas, yakni kalimat kalau matahari hendak masuk ke perhentiannya, ia akan memancarkan sinar merupakan terbanding dan kalimat emas disepuh ke puncak gunung merupakan pembanding. Komponen makna penyama pada kedua contoh kalimat tersebut adalah cahaya yang dipancarkan; tampilan warna. Sementara, komponen makna pembeda, pada kalimat kalau 
matahari hendak masuk ke perhentiannya, ia akan memancarkan sinar bermakna warnah yang dihasilkan oleh matahari saat akan terbenam. Sementara, kalimat emas disepuh ke puncak gunung bermakna emas yang dicampur dengan sendawa, tawas untuk menuakan warna emas. Jadi, matahari hendak masuk ke perhentiannya, ia akan memancarkan sinar diasosiasikan dengan emas disepuh ke puncak gunung karena mempunyai komponen makna penyama. Penanda simile antara pembanding dan terbanding pada contoh di atas adalah kata sebagai.

\section{Contoh (10)}

Air matanya bercucuran, laksana mutiara yang gugur dari karangnya. (hlm.77)

Bagan wilayah terbanding dan pembanding yang diperumpamakan pada contoh di atas adalah pembanding kalimat air matanya bercucuran dengan terbanding kalimat mutiara yang gugur dari karangnya. Komponen makna penyama pada kedua contoh kalimat tersebut adalah sesuatu yang mengalir turun terus menerus. Sementara, komponen makna pembeda, pada kalimat air matanya bercucuran bermakna air mata yang berpancaran turun dari mata; menangis. Sementara, kalimat mutiara yang gugur dari karangnya bermakna mutiara yang jatuh secara bersama-sama dari karangnya. Penanda simile antara pembanding dan terbanding pada contoh di atas adalah kata laksana.

\section{Contoh (11)}

Tiadalah diketahuinya air matanya jatuh bertititk-titik sebagai air mayang enau baru dipancung. (hlm.104)

Bagan wilayah pembanding dan terbanding yang diperumpamakan pada contoh di atas adalah pembanding kalimat air matanya jatuh bertititk-titik dengan terbanding kalimat air mayang enau baru dipancung. Komponen makna penyama pada kedua contoh kalimat tersebut adalah suatu cairan yang menetes berkali-kali. Sementara, komponen makna pembeda, pada kalimat air matanya jatuh bertititk-titik bermakna air mata yang jatuh menetes dari mata. Sementara, kalimat air mayang enau baru dipancung bermakna air mayang enau yang jatuh menetes-netes saat dipancung. Penanda simile antara pembanding dan terbanding pada contoh di atas adalah kata sebagai.

\section{Perwujudan Simile dalam Kelas Kata Verba dengan Nomina}

Perwujudan simile meliputi terbanding dan pembanding. Adapun terbanding berwujud verba dan nomina, begitupula dengan pembanding berwujud nomina dan verba. Perwujudan simile dalam kelas kata verba dengan nomina pada novel $A z a b$ dan Sengsara, sebagai berikut:

\section{Tabel 5}

\section{Perwujudan Simile oleh Merari Siregar dalam Kelas Kata Verba dengan Nomina}

\begin{tabular}{|c|c|c|c|c|c|c|}
\hline \multirow[t]{2}{*}{ No } & \multirow{2}{*}{$\begin{array}{c}\text { Kutipan Teks } \\
\text { Novel Azab dan } \\
\text { Sengsara }\end{array}$} & \multicolumn{2}{|c|}{ Perwujudan Nomina } & \multirow{2}{*}{$\begin{array}{c}\text { Penanda } \\
\text { Terbanding } \\
\text { dan } \\
\text { Pembanding }\end{array}$} & \multirow{2}{*}{$\begin{array}{l}\text { Terbanding } \\
\quad(\mathrm{Teb})\end{array}$} & \multirow{2}{*}{$\begin{array}{l}\text { Pembanding } \\
\quad(\text { Pem })\end{array}$} \\
\hline & & Ter & Pem & & & \\
\hline 1 & $\begin{array}{l}\text { Bunga-bunga } \\
\text { yang } \\
\text { berkembangan di }\end{array}$ & Verba & Nomina & Sebagai & $\begin{array}{l}\text { Bunga-bunga } \\
\text { yang } \\
\text { berkembangan }\end{array}$ & $\begin{array}{l}\text { halaman yang } \\
\text { permai penuh } \\
\text { dengan intan }\end{array}$ \\
\hline
\end{tabular}




\begin{tabular}{|l|l|l|l|l|l|}
\hline $\begin{array}{l}\text { pantai laut tawar, } \\
\text { serta cahaya }\end{array}$ embun yang & & & di pantai laut & permata \\
berhamburan pada & & & & tawar, serta \\
cahaya embun & yang \\
daun rumput- & & & berhamburan \\
rumput adalah & & & pada daun \\
pada mata kita & & & rumput- \\
sebagai halaman & & & & \\
yang permsai & & & & \\
penuh dengan & & & \\
intan permata & & & & \\
(hlm.148) & & & & \\
\hline
\end{tabular}

Contoh (12)

Bunga-bunga yang berkembangan di pantai laut tawar, serta cahaya embun yang berhamburan pada daun rumputrumput adalah pada mata kita sebagai halaman yang permai penuh dengan intan permata (hlm.148)

Bagan wilayah pembanding dan terbanding yang diperumpamakan pada contoh di atas adalah pembanding kalimat bunga-bunga yang berkembangan di pantai laut tawar, serta cahaya embun yang berhamburan pada daun rumput-rumput dengan terbanding kalimat halaman yang permai penuh dengan intan permata. Komponen makna penyama pada kedua contoh kalimat tersebut adalah suatu objek yang indah yang dipenuhi kilauan warna dan cahaya. Sementara, komponen makna pembeda, pada kalimat bunga-bunga yang berkembangan di pantai laut tawar, serta cahaya embun yang berhamburan pada daun rumput-rumput bermakna keindahan bunga-bunga yang tumbuh di pantai laut tawar yang dijatuhi cahaya embun yang menyinari halaman tersebut. Sementara, kalimat halaman yang permai penuh dengan intan permata bermakna halaman yang indah yang dipenuhi dengan kilauan intan permata. Jadi, bunga-bunga yang berkembangan di pantai laut tawar, serta cahaya embun yang berhamburan pada daun rumput-rumput diasosiasikan dengan halaman yang permai penuh dengan intan permata karena memiliki komponen makna penyama. Penanda simile antara pembanding dan terbanding pada contoh di atas adalah kata sebagai.

\section{PENUTUP}

Berdasarkan hasil penelitian dalam pembahasan sebelumnya, dapat disimpulkan beberapa hal yang menjadi temuan dalam penelitian ini terkait perwujudan simile oleh Merari Siregar dalam novel Azab dan Sengsara.

Terdapat lima perwujudan simile oleh Merari Siregar dalam novel Azab dan Sengsara, yakni (1) perwujudan simile dalam kelas kata nomina dengan nomina; (2) perwujudan simile dalam kelas kata nomina dengan adjektiva; (3) perwujudan simile dalam kelas kata adjektiva dengan verba; (4) perwujudan simile dalam kelas kata verba dengan verba; (5) perwujudan simile dalam kelas kata verba dengan nomina. Sementara, penanda simile yang digunakan oleh Merari Siregar dalam novel Azab dan Sengsara, yakni sebagai, ibarat, seperti, tak ubahnya, laksana, dan seolah-olah. 


\section{DAFTAR PUSTAKA}

Ahmadi, M. 1990. Dasar-dasar Komposisi Bahasa Indonesia. Malang: Yayasan Asah Asih Asuh.

Endraswara, Suwardi. 2003. Metodologi Penelitian Sastra (Epistemologi, Model, Teori, dan Aplikasi). Yogyakarta: PN. Pustaka Widyatama.

Fananie, Zainuddin. 2000. Telaah Sastra. Surakarta: Muhammadiyah University Press.

Iye, Risman and Susiati. 2018. "Nilai Edukatif dalam Novel Sebait Cinta di Bawah Langit Kairo Karya Mahmud Jauhari Ali (Educative Values in Sebait Cinta di Bawah Langit Kairoby Mahmud Jauhari Ali). Sirok Bastra, 6 (2), 185-191.

Jabrohim. 2000. Metodologi Penelitian Sastra. Yogyakarta: Hanindita Graha Widya.

Junus, Umar. 1989. Stilistika: Suatu Pengantar. Kuala Lumpur: Dewan Bahasa dan Pustaka Kementerian Pendidikan Malaysia.

Keraf, Gorys. 2010. Diksi dan Gaya Bahasa. Jakarta: PT Gramedia Pustaka Utama.

Kridalaksana, Harimurti. 2009. Kelas Kata Dalam Bahasa Indonesia. Jakarta: PT Gramedia Pustaka Utama.

2011. Kamus Linguistik. Edisi Ketiga. Jakarta: PT Gramedia Pustaka Utama.

Mahsun. 2013. Metode Penelitian Bahasa (Tahapan Strategi, Metode dan Tekniknya). Jakarta: PT Raja Grafindo Persada.
Moleong, Lexi. 2007. Metodologi Penelitian Kualitatif. Bandung: Remaja Rosdakarya.

Munir, Saiful, Nas Haryati S., dan Mulyono. 2013. "Diksi dan Majas dalam Kumpulan Puisi Nyanyian dalam Kelam Karya Sutikno W. S: Kajian Stilistika". Jurnal Sastra Indonesia. Vol. 2, No. 1.

Nurgiyantoro, Burhan. 2002. Teori Pengkajian Fiksi. Yogyakarta: Gadjah Mada University Press. . 2014. Stilistik. Yogyakarta: Gadjah
Mada University Press.

Abrams, M.H. 1976. The Mirror and The Lamp : Romantic Theory and The Critical Tradition. New York: Holt, Rinehart and Winston.

Aminuddin. 1995. Stilistika: Pengantar Memahami Bahasa dalam Karya Sastra. Semarang: IKIP Semarang Press.

Bradford, Richard. 1997. Stylistics. London: New Fetter Lane.

Bressler, Charles E. 1999. Literary Criticism : An Introduction to Theory and Practice. Second Edition. New Jersey: Prentice Hall, Upper Saddle River.

Child, Peter and Roger Fowler. 2006. The Routledge Dictionary of Literary Terms. London and New York: Routledge.

Darmono, S. D. 2003. Kita dan Sastra Dunia. dalam http://www.mizan.com. diakses pada tanggal 13 Januari 2012.

Darwis, Muhammad. 2002. Pola-Pola Gramatikal dalam Puisi Indonesia. Dalam Jurnal Masyarakat Linguistik Indonesia edisi Tahun 20, Nomor 1, Februari 2002. 
Davies, Alan and Catherine Elder (Ed). 2006. The Handbook of Applied Linguistics. Australia: Blackwell Publishing.

Depdiknas. 2005. Kamus Besar Bahasa Indonesia (edisi 3). Jakarta: Balai Pustaka.

Endaswara, Suwardi. 2003. Metodologi Penelitian Sastra. Yogyakarta: Pustaka Widyatama.

Fabb, Nigel. 2003. Linguistics and Literature. In Mark Arnoff and Janie Rees-Miller (Ed), The Handbook of Linguistics. USA: Blackwell Publisher.

Junus, Umar. 1989. Stilistika : Satu Pengantar. Kuala Lumpur: Dewan Bahasa dan Pustaka.

Keraf, Gorys. 2006. Diksi dan Gaya Bahasa (cetakan XVI). Jakarta: PT Gramedia Pustaka Utama.

Keraf, Gorys. 2009. Diksi dan Gaya bahasa. Jakarta: Gramedia Pustaka Utama.

Kridalaksana, Harimurti. 2001. Kamus Linguistik (edisi IV). Jakarta: PT Gramedia Pustaka Utama.

Mikics, David. 2007. A New Handbook of Literary Term. London: Yale University Press.

Mills, Sara. 1995. Feminist Stylistics. London and New York: Routledge.

Missikova, Gabriela. 2003. Linguistics Stylistics. Nitra: Filozoficka Fakulta Univerzita Konstantina Filozofa.

Musthafa, Bachrudin. 2008. Teori dan Praktik Sastra dalam Penelitian dan Pengajaran. Bandung: UPI.

Nurgiyantoro, Burhan. 1995. Teori Pengkajian Fiksi. Yogyakarta: Gadjah Mada University Press.
Nurgiyantoro, Burhan. 2005. Teori Pengkajian Fiksi. Yogyakarta: Gajah Mada University Press.

Pradopo, Rachmat Djoko. 1997. Pengkajian Puisi Analisis Strata Norma dan Analisis Struktural dan Semiotik. Yogyakarta: Gadjah Mada University Press.

Pranawa, Erry. 2005. Analisis Stilistika Novel Burung-burung Manyar Karya Y.B. Mangunwijaya (Tesis). Program Studi Linguistik Pascasarjana Universitas Sebelas Maret Surakarta.

Ratna, Nyoman Kutha. 2009. Stilistika Kajian Puitika Bahasa Sastra dan Budaya. Yogyakarta: Pustaka Pelajar.

Renne Wellek \& Austin Warren, 1995. Penerjemah Melani Budianta, Teori Kesusastraan, Jakarta : PT Gramedia Pustaka Utama.

Sangidu. 2004. Penelitian Sastra Pendekatan Teori, Metode, Teknik dan Kiat. Yogyakarta: Unit Penerbitan Asia Barat.

Satoto, Soediro. 1995. Stilistika. Surakarta: STSI Press.

Sayuti, Suminto A. 2001. Penelitian Stilistika : Beberapa Konsep Pengantar. Dalam Jabrohim (Ed) Metodologi Penelitian Sastra. Yogyakarta: Hanindita.

Shipley, Joseph T. 1979. Dictionary of World Literature : Forms, Technique, Critics.. USA: Boston The Writer, Inc.

Simpson, Paul. 2004. Stylistics : A Resource Book for Student. New York: Roudledge.

Starcke, Bettina Fischer. 2010. Corpus Linguistics in Literary Analysis. New York: Continuum nternationa Publishing Group. 
Sudjiman, Panuti. 1993. Bunga Rampai Stilistik. Jakarta: Pustaka Utama Grafiti.

Suprapto. 1991. Kumpulan Istilah Sastra dan Apresiasi Sastra. Jakarta: Dian.

Tuloli, Nani. 2000. Kajian Sastra. Gorontalo: Nurul Jannah.

Lafamane, F. (2020). Tata Bahasa Fungsional (functional Grammar).

Lafamane, F. (2020). Fenomena Penggunaan Bahasa Daerah di Kalangan Remaja.

Amanto, B. S., Umanailo, M. C. B., Wulandari, R. S., Taufik, T., \& Susiati, S. (2019). Local Consumption Diversification. Int. J. Sci. Technol. Res, 8(8), 1865-1869.

Amri, M., Tahir, S. Z. A. B., \& Ahmad, S. (2017). The Implementation of Islamic Teaching in Multiculturalism Society: A Case Study at Pesantren Schools in Indonesia. Asian Social Science, 13(6), 125.

Andini, K. NILAI BUDAYA SUKU BAJO SAMPELA DALAM FILM THE MIRROR NEVER LIES KARYA KAMILA ANDINI.

ARYANA, A. PERBANDINGAN GAYA BAHASA DALAM NOVEL ATHEIS KARYA ACHDIAT KARTA MIHARDJA DAN NOVEL TELEGRAM KARYA PUTU WIJAYA: TINJAUAN STILISTIKA.

Azwan, A. (2018). Politeness strategies of refusals to requests by Ambonese community. LINGUA: Jurnal Bahasa, Sastra, Dan Pengajarannya, 15(1), 1-6.

Crystal, David. 2000. New Perspectives of Language Study 1 : Stylistics. University of Reading: Department of Linguistics Science.
Djamudi, N. L., Nurlaela, M., Nazar, A., Nuryadin, C., Musywirah, I., \& Sari, H. (2019, October). Alternative social environment policy through educational values in Kafi'a's customary speech to the kaledupa community of Wakatobi Island, Indonesia. In IOP Conference Series: Earth and Environmental Science (Vol. 343, No. 1, p. 012118). IOP Publishing..

Indonesia, K. K. D. B. Morfologi Bahasa Indonesia.

Iye, R., \& Susiati, S. (2018). NILAI EDUKATIF DALAM NOVEL SEBAIT CINTA DI BAWAH LANGIT KAIRO KARYA MAHMUD JAUHARI ALI (Educative Values in Sebait Cinta di Bawah Langit Kairo by Mahmud Jauhari Ali). Sirok Bastra, 6(2), 185191.

lye, R., Susiati, S., \& Karim, K. (2020). Citra Perempuan dalam Iklan Sabun Shinzui. Sang Pencerah: Jurnal Ilmiah Universitas Muhammadiyah Buton, 6(1), 1-7.

Karim, K., Maknun, T., \& Abbas, A. (2019). Praanggapan Dalam Pamflet Sosialisasi Pelestarian Lingkungan Di Kabupaten Wakatobi. Jurnal Ilmu Budaya, 7(2), 241-247.

Lafamane, F. (2020). Tata Bahasa Sistemik Fungsional (Suatu Pandangan).

Lafamane, F. (2020). Perkembangan Teori Sastra (suatu Pengantar). OSF Preprints. July, 25.

Mansyur, F. A., \& Suherman, L. A. (2020). The Function of Proverbs as Educational Media: Anthropological Linguistics on Wolio Proverbs. ELS Journal on Interdisciplinary Studies in Humanities, 3(2), 271-286. 
Rahayaan, I., Azwan, A., \& Bugis, R. (2016). The Students' Writing Ability through Cooperative Script Method. Jurnal Retemena, 2(2).

Sadat, A., Nazar, A., Suherman, L. O. A., Alzarliani, W. O. D., \& Birawida, A. B. (2019, October). Environmental care behavior through e-jas model with science edutainment approach. In IOP Conference Series: Earth and Environmental Science (Vol. 343, No. 1, p. 012126). IOP Publishing.

Sadat, A., Sa'ban, L. M. A., Suherman, L. O. A., Bahari, S., Ibrahim, T., \& Zainal, M. (2019, October). Internalization characters of environmental care and disaster response through care partner schools. In IOP Conference Series: Earth and Environmental Science (Vol. 343 , No. 1, p. 012125). IOP Publishing.

Salamun, T. (2018). DEIKSIS PERSONA BAHASA INDONESIA DIALEK AMBON [Personal Deixes of Indonesian Leanguage With Ambonese Dialect]. Totobuang, 5, 325-339.

Salamun, T. (2018). RELASI KEKERABATAN BAHASA HITU, WAKAL, MORELA, MAMALA, DAN HILA DI PROVINSI MALUKU [The Family Relationship Language Hitu, Wakal, Morela, Mamala, and Hila in Maluku Province].

Suherman, L. A. (2018). The Analysis of Metaphorical Domain on English "Stab Verb" in Corpora. ELS Journal on Interdisciplinary Studies in Humanities, 1(1), 52-58.

Suherman, L. O. A., Salam, S., Mursanto, D., Efendi, A., Bahar, S. B., \& Kanna, T. (2019, October). The effect of open-air curing on compressive strength of geopolymer mortar containing laterite soil and slaked lime. In IOP Conference Series: Earth and Environmental Science (Vol. 343, No. 1, p. 012133). IOP Publishing.
Susiati, S., \& Iye, R. (2018). Kajian Geografi Bahasa dan Dialek di Sulawesi Tenggara: Analisis Dialektometri. Gramatika: Jurnal IImiah Kebahasaan dan Kesastraan, 6(2), 137-151.

Susiati, S. Dialektometri Segitiga: Hubungan Kekerabatan Bahasa Di Sulawesi Tenggara (Bahasa Wakatobi, Bahasa Cia-Cia, Bahasa Pancana, Bahasa Kioko, Bahasa Tolaki).

Susiati, S., lye, R., \& Suherman, L. O. A. (2019). Hot Potatoes Multimedia Applications in Evaluation of Indonesian Learning In SMP Students in Buru District. ELS Journal on Interdisciplinary Studies in Humanities, 2(4), 556-570.

Susiati, S. (2018). Homonim bahasa kepulauan tukang besi dialek kaledupa di kabupaten wakatobi [the homonymon of tukang besi island languange in kaledupa dialect at wakatobi regency]. Totobuang, 6 (1), 109, 123.

Susiati, S. (2020). Emosi Verbal Suku Bajo Sampela.

Susiati, S. (2020). Fenomena Tuturan Emosi Verbal Bahasa Indonesia Suku Bajo Sampela.

Susiati, S. (2020). Nilai Budaya Suku Bajo Sampela Dalam Film The Mirror Never Lies Karya Kamila Andini.

Susiati, S. (2020). Konsep Pertentangan Dalam Film" Aisyah Biarkan Kami Bersaudara" Karya Herwin Novianto.

Susiati, S. (2020). Strategi AMBT untuk Meningkatkan Kemampuan Membaca Pemahaman Interpretatif Siswa Kelas IV SD Negeri 3 Namlea Kabupaten Buru.

Susiati, S. (2020). Fungsi Konatif Pada Iklan Mesin Cuci Hole-Less Tub Dari Sharp: Analisis Wacana Kritis. 
Susiati, S. (2020). GAYA BAHASA SECARA UMUM DAN GAYA BAHASA PEMBUNGKUS PIKIRAN.

Susiati, S. (2020). The Concept Of Togetherness In The Films" Aisyah Biarkan Kami Bersaudara" By Herwin Novianto.

Susiati, S. (2020). Konsep Kebersamaan Dalam Film" Aisyah Biarkan Kami Bersaudara" Karya Herwin Novianto.

Susiati, S. (2020). Teori dan Aliran Linguistik: Tata Bahasa Generatif.

Susiati, S. (2020). Metode Pembelajaran Bahasa Indonesia: Sosiodrama.

Susiati, S. (2020). Rekontruksi Internal Bahasa Bugis dan Bahasa Makassar: Linguistik Komparatif.

Susiati, S. Bahan Ajar: Psikolinguistik.

Susiati, S. (2020). PENTINGNYA MELESTARIKAN BAHASA DAERAH.

Susiati, S. (2020). Morfologi Kelas Kata Dalam Bahasa Indonesia.

Susiati, S. (2020). Semantik: Teori Semantik, Relasi Makna, Marked, Dan Unmarked.

Susiati, Y. T. Risman lye. A. Kesantunan Imperatif Bahasa Indonesia Suku Bajo Sampela: Balai Pembinaan dan Pengembangan Bahasa. 2018. Kongres Bahasa Indonesia (No. 12, pp. 16). Report.

Susiati, S. (2020). Internal Recontruction Bugis Language and Makassar Language.

Susiati, S. (2020). Kesantunan Imperatif Bahasa Melayu Ambon.
Susiati, S. (2020). Gaya Bahasa Secara Umum Dan Gaya Bahasa Pembungkus Pikiran: Stilistika.

Susiati, S. (2020). Tuturan Kesantunan Imperatif Bahasa Indonesia Suku Bajo Sampela.

Susiati, S. (2020). Nilai Budaya Suku Bajo Sampela Dalam Film The Mirror Never Lies Karya Kamila Andini.

Susiati, S. (2020). Pengaplikasian Multimedia Hot Potatoes Dalam Evaluasi Pembelajaran Bahasa Indonesia Pada Siswa SMP Negeri 9 Buru.

Susiati, S., \& Iye, R. (2018). Kajian Geografi Bahasa dan Dialek di Sulawesi Tenggara: Analisis Dialektometri. Gramatika: Jurnal Ilmiah Kebahasaan dan Kesastraan. 6 (2), 137-151.

Susiati, S. (2020). Kaidah Fonologi Bahasa Indonesia.

Susiati, S. (2020). Wujud Morfologi Bahasa Indonesia.

Susiati, S. (2020). Makian Bahasa Wakatobi Dialek Kaledupa.

Susiati, S. (2020). Eksistensi Manusia Dalam Film" Aisyah Biarkan Kami Bersaudara" Karya Herwin Novianto.

Susiati, S. NILAI BUDAYA SUKU BAJO SAMPELA DALAM FILM THE MIRROR NEVER LIES.

Susiati, S. (2020). Konsep Keterasingan Dalam Film" Aisyah Biarkan Kami Bersaudara" Karya Herwin Novianto.

Susiati, S. (2020). Concept Of Conflict In The Films "AISYAH BIARKAN KAMI BERSAUDARA" By Herwin Novianto.

Susiati, S. (2020). Embrio Nasionalisme Dalam Bahasa dan Sastra. 
Susiati, S. PERWUJUDAN SIMILE OLEH MERARI SIREGAR DALAM NOVEL AZAB DAN SENGSARA.

Susiati, S. (2020). Nilai Pembentuk Karakter Masyarakat Wakatobi Melalui Kabhanti Wa Leja.

Tahir, S. Z. A. B. (2017). Pengembangan Materi Multibahasa untuk Siswa Pesantren. Unpublish dissertation.

Tahir, S. Z. B. (2015). Multilingual Teaching And Learning At Pesantren. 14 Asian EFL Journal Conference.

Tenriawali, A. Y. (2018). Representasi korban kekerasan dalam teks berita daring tribun timur: analisis wacana kritis [the representation victims of violence in tribun timur online news text: critical discourse analysis]. TOTOBUANG, 6 (1), 1, 15.

Yusdianti, A. (2020). THE REPRESENTATION VICTIMS OF VIOLENCE IN TRIBUN TIMUR ONLINE NEWS TEXT: CRITICAL DISCOURSE ANALYSIS.

Verdonk, Peter. 2002. Stylistics. New York: Oxford University Press.

Wellek, Rene dan Austin Warren. 1989. Teori Kesusastraan. Diterjemahkan oleh Melani Budianta. Jakarta: Gramedia.

Widdowson, H.G. 1997. Stilistika dan Pengajaran Sastra. Diterjemahkan oleh Sudijah. Surabaya: Airlangga University Press.

Wynne, Martin. 2005. Stylistics : Corpus Approaches. Oxford: Oxford University.

Yunus, Umar. 1989. Stilistika; Suatu Pengantar. Kuala Lumpur : Dewan Bahasa dan Pustaka.
Zhang, Zhiqin. 2010. The Interpretation of a Novel by Hemingway in Term of Literary.

Zulfahnur, dkk. 1996. Teori Sastra. Jakarta: Depdikbud

Rachman, Abdul, Chairil Effendy, dan Totok Priyadi. 2013. "Majas Metafora pada Kumpulan Sajak Chairil Anwar Aku Ini Binatang Jalang". Jurnal Pendidikan dan Pembelajaran. Vol 2, No. 6.

Ratna, Nyoman Kutha. 2016. Stilistika Kajian Puitika Bahasa, Sastra, dan Budaya. Yogyakarta: Pustaka Pelajar.

Semi, M. Atar. 1989. Kritik Sastra. Bandung: Angkasa.

Siregar, Merari. 1993. Azab dan Sengsara. Jakarta: Balai Pustaka.

Sudjiman, Panuti. 1993. Bunga Rampai Stilistika. Jakarta: Pustaka Utama.

Susiati, Susiati, and Risman Iye. 2018. "Kajian Geografi Bahasa dan Dialek di Sulawesi Tenggara: Analisis Dialektometri”. Gramatika. Vol. 6. No. 2. 137-151.

Susiati. 2017. "Majas Dalam Novel Azab dan Sengsara Karya Merari Siregar". Jurnal Welia. Vol. 2. No. 2.

Tarigan, Henry Guntur. 1986. Pengajaran Semantik. Bandung: Angkasa. 
